\title{
The Methodology of the Research on Language Aptitude: A Systematic Review - ERRATUM
}

Shaofeng Li and Huijun Zhao

In the above article ( $\mathrm{Li} \& \mathrm{Zhao}, 2021)$, the following reference was originally missing:

Spada, N., \& Tomita, Y. (2010). Interactions between type of instruction and type of language feature: A meta-analysis. Language Learning, 60, 263-308.

Also, the reference "Implicit language aptitude: Conceptualizing the construct, validating the measures, and examining the evidence. Studies in Second Language Acquisition." should be credited to Li, S., \& DeKeyser, R. (in press).

The publisher apologizes for these errors.

\section{Reference}

Li, S., \& Zhao, H. (2021). The Methodology of the Research on Language Aptitude: A Systematic Review. Annual Review of Applied Linguistics, 41, 25-54. doi:10.1017/S0267190520000136.

Cite this article: Li, S., \& Zhao, H. (2021). The Methodology of the Research on Language Aptitude: A Systematic Review - ERRATUM. Annual Review of Applied Linguistics, 41, 126-126. https://doi.org/ $10.1017 /$ S0267190521000064

(c) The Author(s) 2021. Published by Cambridge University Press 